\title{
Primula vulgaris Yaprak Ekstraktının Antioksidan ve Sitotoksik Özelliklerinin Değerlendirilmesi
}

\author{
İbrahim TURAN ${ }^{1}$ \\ Selim DEMİ ${ }^{2}$ \\ Rezzan ALIYAZICIOĞLU ${ }^{3}$ \\ Yüksel ALIYYAZICIOĞLU ${ }^{4}$ \\ ${ }^{1}$ Gümüşhane Üniv. Mühendislik ve Doğa Bilimleri Fakültesi, Genetik ve Biyomühendislik Böl. 29100, Gümüşhane, \\ ${ }^{2}$ Karadeniz Teknik Üniversitesi, Sağlık Bilimleri Fakültesi, Beslenme ve Diyetetik Bölümü, 61080, Trabzon, \\ ${ }^{3}$ Karadeniz Teknik Üniv. Eczacılık Fakültesi, Temel Eczacılık Bölümü, Biyokimya ABD, 61080, Trabzon, \\ ${ }^{4}$ Karadeniz Teknik Üniv. Tıp Fakültesi, Temel Tıp Bölümü, Tıbbi Biyokimya ABD, 61080, Trabzon \\ $\varangle$ : selim-demir@hotmail.com
}

\begin{abstract}
ÖZET: Primula vulgaris, Primula cinsine mensup bir bitki olup, bu bitkiler siklıkla geleneksel tedavide kullanılmaktadırlar. Farklı Primula türlerinin farklı ekstraktlarının antioksidan ve sitotoksik etkilerini konu alan çok sayıda çalışma olmasına rağmen, $P$. vulgaris ekstraktlarının bu özellikleri ile ilgili sınırlı sayıda çalışma bulunmaktadır. $\mathrm{Bu}$ çalışmanın amacı $P$. vulgaris yapraklarının dimetil sülfoksitli ekstraktının antioksidan özelliklerinin ve sitotoksik etkilerinin belirlenmesidir. Ekstraktın toplam fenolik madde miktarı, toplam flavonoid madde miktarı ve indirgeyici antioksidan güç tayini spektrofotometrik yöntemler kullanılarak belirlendi. Ekstraktın sitotoksik etkisi ise insan akciğer (A549), karaciğer (HepG2), meme (MCF-7), prostat (PC-3) ve kolon (WiDr) kanser hücre serileri ile normal insan fibroblast hücre serisi üzerinde MTT yöntemi kullanılarak değerlendirildi. Ekstraktın toplam fenolik madde içeriği ve indirgeyici antioksidan güç değerleri $100 \mathrm{~g}$ örnek başına sırasıyla $1890.1 \pm 11.2 \mathrm{mg}$ gallik asit eşdeğeri ve 3233.1 $\pm 176.2 \mathrm{mg}$ troloks eşdeğeri olarak bulundu. Ekstrakt çalışılan tüm kanser hücre serileri üzerinde normal fibroblast hücrelerine göre seçici sitotoksik etki gösterdi ve $\mathrm{IC}_{50}$ değerleri $133.3-253.8 \mu \mathrm{g} / \mathrm{mL}$ arasında hesaplandı. Bu çalışma $P$. vulgaris yaprak ekstraktının antioksidan özelliklerini ve kanser hücre serileri üzerindeki sitotoksik etkisini ortaya koyan ilk çalışmadır. Ekstraktta bulunan antioksidan ve sitotoksik etki gösteren molekülleri ve bu etkilerin mekanizmalarını belirleyebilmek için daha ileri çalışmalar gerekmektedir.
\end{abstract}

Anahtar kelimeler: Antioksidan aktivite, Kanser, Primula vulgaris, Sitotoksisite

\section{Evaluation of Antioxidant and Cytotoxic Properties of Primula vulgaris Leaf Extract}

\begin{abstract}
Primula vulgaris belongs to the genus Primula and this genus is frequently used in traditional medicine. Numerous studies reported the antioxidant and cytotoxic effects of various extracts of different Primula species but, there were limited studies of the antioxidant and cytotoxic effect of $P$. vulgaris. The aim of this study was to determine the antioxidant properties and cytotoxic effects of dimethyl sulfoxide extract of leaves of P. vulgaris. The total polyphenolic content (TPC), total flavonoid content (TFC) and reducing antioxidant power of extract were evaluated using spectrophotometric procedures. The cytotoxic effects of extract were revealed on human lung (A549), liver (HepG2), breast (MCF-7), prostate (PC-3), and colon (WiDr) cancer cell lines and normal fibroblast cells using thiazolyl blue tetrazolium bromide (MTT) assay. TPC and FRAP values were $1890.1 \pm 11.2 \mathrm{mg}$ gallic acid equivalents and $3233.1 \pm 176.2 \mathrm{mg}$ trolox equivalents per $100 \mathrm{~g}$ sample, respectively. The extract showed selective cytotoxic effects on all studied cancer cell lines compared to normal fibroblast cells and $\mathrm{IC}_{50}$ values ranged from 133.3 $-253.8 \mu \mathrm{g} / \mathrm{mL}$. This is the first study to reveal the antioxidant properties of $P$. vulgaris leaf extract and its cytotoxic effect on cancer cell lines. Further studies are now needed to identify the antioxidant and cytotoxic molecules in the extract and their mechanisms.
\end{abstract}

Key words: Antioxidant activity, Cancer, Cytotoxicity, Primula vulgaris

\section{GíRIş}

Kanser küresel bir sağlık sorunu olup, gelişmiş ve gelişmekte olan ülkelerdeki ölümlerin sırasıyla \% 21 ve \% 9'unun kanser kaynaklı olduğu bildirilmektedir. Dünya Sağlık Örgütü'nün 2050 yılı tahminlerinde yıllık yaklaşık 27 milyon yeni kanser vakası ve 17.5 milyon kansere bağlı ölüm öngörülmektedir (Hussain ve ark. 2016). Pek çok kanser hastasının tedavisinde sıklıkla kemoterapi ve radyoterapiye başvurulmakla birlikte, bu tedavilerin zamanla normal hücrelere de zarar vermesi ve hedeflenen kanser hücrelerinde direnç oluşması bu terapilerin başarı yüzdesini düşürmektedir (Behzad ve ark. 2016). Bu nedenle güncel araştırmalar daha az yan etkiye sahip yeni nesil ilaç geliştirme çalışmaları üzerine yoğunlaşmaktadır (Unnati ve ark. 2013).

Bitkiler eski çağlardan beri pek çok insan ve hayvan hastalığına karşı gerek koruyucu gerekse de tedavi edici amaçlarla kullanılmışlardır. Günümüzde kanser hücre çoğalmasını durdurabilmek için kullanılan ilaçların yaklaşık \% 50'si bitkilerden elde edilmektedir. Dünya Sağlık Örgütü verilerine göre gelişmekte olan ülkelerde yaşayan insanların \% 80'inden fazlası primer sağlık sorunlarını gidermede doğal ürünlere başvurmaktadır. Son yapılan anketler kanser hastalarının \% 60'ından fazlasının terapi amacıyla doğal ürünleri kullandığını ortaya koymaktadır. Bununla birlikte tıbbi bitkilerin çok az bir kısmı antikanser özellikleri bakımından bilimsel 
olarak değerlendirilebilmiştir. Bu nedenle özellikle son yıllarda doğal ürünlerden yeni nesil antikanser ilaç geliştirme çalışmaları hem bilimsel hem de ticari çevrelerde büyük bir ilgiyle karşılanmaktadır (Unnati ve ark. 2013). Primula; Primulaceae ailesine mensup bir bitki cinsi olup, Kuzey Yarımküre'de nemli ve 1lıman iklim bölgelerinde yetişen 400 'den fazla tür içermektedir (Aslam ve ark. 2014). Primula türleri geleneksel tedavide bronşit, astım, uykusuzluk gibi rahatsızlıklara karşı kullanılmaktadırlar (Najmus-Saqib ve ark. 2009; Orhan ve ark. 2012). Primula türlerinin saponinler, alkaloidler, tanninler, terpenler ve fenolik bileşiklerce zengin olduğu bildirilmektedir (Mostafa ve ark. 2014; Aslam ve ark. 2015). Primula türlerinin antioksidan, antimikrobiyal, antigenotoksik, anti-inflamatuvar, hipoglisemik ve yara iyileştirici özellikleri çeşitli çalışmalarla ortaya konulmuştur ve bu faydalı biyolojik özellikler yukarıda adı geçen bileşiklerin varlığına atfedilmektedir (Orhan ve ark. 2012; Mostafa ve ark. 2014; Singh ve ark. 2014; Aslam ve ark. 2015). Primula türleri bu faydalı biyolojik özelliklerinin belirlenmesinin ardından özellikle son yıllarda başta gıda ve kozmetik sanayi olmak üzere çeşitli ticari çevrelerin ilgisini toplamaktadır (Demir ve ark. 2014). Primula türlerinin kanser hücreleri üzerindeki sitotoksik etkinliğini konu alan çalışmalarda ise; Primula vulgaris çiçek ve yapraklarının sulu ekstraktlarının sitotoksik etkisi brine shrimp yöntemi ile incelenmiş ve $\mathrm{LC}_{50}$ değerleri sirasıyla 311 ve $40 \mu \mathrm{g} / \mathrm{mL}$ olarak bulunmuştur (Turker ve Usta, 2008). Behzad ve ark. (2016) ise Primula auriculata'nın metanollü ekstraktının insan kolon kanseri (HT-29) hücre serisinde kaspaz aktivasyonu sağlayarak apoptotik özellik sergilediğini göstermişlerdir. Böyle olduğu halde literatürde $P$. vulgaris ekstraktlarının sitotoksik etkinliğini konu alan sınırlı sayıda çalışma olduğu görülmektedir. Buradan hareketle hazırlananan bu çalışmanın amacı; Primula vulgaris yapraklarından dimetil sülfoksit (DMSO) ile hazırlanan ekstraktın antioksidan özelliklerinin tespit edilmesi ve ekstraktın insan akciğer (A549), karaciğer (HepG2), meme (MCF-7), prostat (PC-3) ve kolon (WiDr) kanser hücre serileri ile normal insan fibroblast hücre serisi üzerindeki sitotoksik etkisinin belirlenmesidir.

\section{MATERYAL ve METOT}

\section{Kullantlan Kimyasal Maddeler}

Antioksidan aktivite analizlerinde kullanılan tüm kimyasallar analitik sınıfı saflıkta olup Sigma-Aldrich (St. Louis, ABD) firmasından satın alındı. Hücre kültüründe kullanılan EMEM (Eagle's Minimum Essential Medium) besiyeri ile tripsin çözeltisi Lonza (Verviers, Belçika), fetal bovin serum (FBS) Biochrom (Berlin, Almanya) ve gentamisin ise Biological Industries (Kibbutz Beit Haemek, İsrail) firmalarından temin edildi.

\section{Kullanilan Laboratuvar Cihazlart}

$\mathrm{Bu}$ çalışma yapılırken laboratuvar değirmeni (Retsch ZM 200, Haan, Almanya), mikropleyt okuyucu (Molecular Devices Versamax, California, ABD), hücre kültürü kabini (Heraeus KS-12, Langenselbold, Almanya), $\mathrm{CO}_{2}$ inkübatörü (Thermo Forma 381, Marietta, ABD), ters faz mikroskop (Nikon Eclipse TS100, Tokyo, Japonya), santrifüj (Eppendorf 5804, Hamburg, Almanya) ve hassas analitik terazi (Mettler Toledo AB204-S, Greifensee, İsviçre) gibi laboratuvar cihazları kullanıldı.

\section{Bitkisel Materyal}

Çalışmada kullanılan Primula vulgaris bitki örnekleri 2015 y1lı ilkbahar mevsiminde Trabzon'dan toplandı. Bitkinin tür teșhisi Karadeniz Teknik Üniversitesi Eczacılık Fakültesi öğretim üyesi Prof. Dr. Ufuk Özgen tarafindan yapıldı.

\section{Ekstraksiyon}

Bitki numuneleri oda sıcaklığında 20 gün boyunca kurutuldu, süre sonunda yaprak kısımları dikkatlice ayrılıp laboratuvar değirmeni yardımıyla toz haline getirildi. Toz haline getirilmiş örneklerden $0.5 \mathrm{~g}$ alınarak $10 \mathrm{~mL}$ DMSO ile karıştırıldı. Karışım iyice vortekslendikten sonra $45^{\circ} \mathrm{C}$ 'de 150 rpm'de sürekli çalkalanarak 24 saat inkübasyona birakıldı. İnkübasyondan sonra karışım 2000×g'de 10 dakika santrifüjlendi. Süpernatant süzgeç kağıdından süzüldü ve ardından $0.2 \mu \mathrm{m}$ 'lik filtrelerden geçirildi. Elde edilen DMSO'lu ekstrakt deneylerde kullanılmak üzere alikotlanıp $-20^{\circ} \mathrm{C}$ 'de, karanlıkta sakland 1 .

\section{Toplam Fenolik Madde Tayini}

Ekstraktının toplam fenolik madde içeriği, modifiye edilmiş Folin-Ciocalteu metoduna göre spektrofotometrik olarak belirlendi (Slinkard ve Singleton, 1977). $12.5 \mu \mathrm{L}$ örnek, $62.5 \mu \mathrm{L} \quad 1: 10$ seyreltilmiş Folin reaktifi ve $125 \mu \mathrm{L} \%$ 20'lik sodyum karbonat çözeltisi ile karıştırılıp oda sıcaklığında, karanlıkta 30 dakika inkübe edildi. Süre sonunda 760 nm'de mikropleyt okuyucuda absorbans ölçümü gerçekleştirildi. Standart olarak gallik asit kullanıldı ve fenolik madde miktarı mg gallik asite eşdeğer/100 g örnek olarak hesapland1.

\section{Toplam Flavonoid Madde Tayini}

Ekstraktın toplam flavonoid içeriği, alüminyum klorür kolorimetrik metodu ile belirlendi (Moreno ve ark. 2000). $20 \mu \mathrm{L}$ örnek; $172 \mu \mathrm{L} \% 80$ 'lik etanol, $4 \mu \mathrm{L} \%$ 10'luk alüminyum klorür ve $4 \mu \mathrm{L} 1 \mathrm{M}$ potasyum asetat çözeltisi ile karıştırılıp oda sıcaklığında, karanlıkta 40 dakika inkübe edildi. Süre sonunda $415 \mathrm{~nm}$ 'de mikropleyt okuyucuda absorbans ölçümü gerçekleştirildi. Standart olarak kuersetin kullanıldı ve flavonoid madde miktarı mg kuersetine eşdeğer/100 g örnek olarak hesapland1.

\section{Demir Indirgeyici Gücün Belirlenmesi}

Demir indirgeyici gücün belirlenmesi için Oyaizu'nun geliştirdiği yöntem modifiye edilerek kullanıldı (Oyaizu, 1986). $40 \mu \mathrm{L}$ numune; $100 \mu \mathrm{L} 0.2 \mathrm{M}$ fosfat tamponu ( $\mathrm{pH}: 6.6$ ) ve $100 \mu \mathrm{L}$ potasyum ferrisiyanat ile karıştırılıp, karanlıkta $50^{\circ} \mathrm{C}$ 'de 20 dakika inkübe edildi 
ve süre sonunda su altında soğutuldu. Karışımın üzerine $100 \mu \mathrm{L} \% 10$ 'luk trikloroasetik asit ilave edildi ve karışım $2000 \times$ g'de 10 dakika santrifüjlendi. Üst fazlardan 100'er $\mu \mathrm{L}$ örnek alınarak 96 kuyucuklu mikropleyte aktarıldı ve üzerine $100 \mu \mathrm{L}$ distile su ve $20 \mu \mathrm{L}$ demir (III) klorür ilave edildi. Son karışım oda sıcaklığında, karanlıkta 5 dakika inkübe edildi. Süre sonunda $700 \mathrm{~nm}$ 'de mikropleyt okuyucuda absorbans ölçümü gerçekleştirildi. Standart olarak troloks kullanıldı ve demir indirgeyici güç mg troloksa eşdeğer/100 g örnek olarak hesaplandı.

\section{Hücre Kültürï}

Çalışmada kullanılan A549 (CCL-185), HepG2 (HB8065), MCF-7 (HTB-22), PC-3 (CRL-1435) ve WiDr (CCL-218) insan kanser hücre serileri ile normal insan fibroblast (CRL-2522) hücre serisi Amerikan Tip Kültür Koleksiyonu (ATCC)'den satın alındı. Hücreler \% 10 fetal bovine serum (FBS) ve \% 1 gentamisin ile zenginleştirilmiş L-glutamin içeren EMEM besiyeri içerisinde $\% \quad 5 \quad \mathrm{CO}_{2}$ ortamında, $37^{\circ} \mathrm{C}$ 'de, T-75'lik flasklarda, inkübatörde çoğaltıldı.

\section{Sitotoksisite Analizleri}

Ekstraktın kanser hücre serileri üzerindeki sitotoksik etkisinin belirlenmesinde MTT metodu modifiye edilerek kullanıldı (Mosmann, 1983). Sitotoksisite deneylerinde pozitif kontrol olarak cisplatin kullanıldı. Cisplatin DMSO ile çözüldü ve ara stok çözeltileri hücre kültürü besiyeri ile hazırlandı. Hücrelerin maruz kaldığ 1 final DMSO konsantrasyonu tüm deneylerde \% 0.5 'in altında tutuldu. Tripsinizasyon ile flasklardan kaldırılan hücreler sayıldıktan sonra 96 kuyucuklu steril hücre kültür pleytinin her kuyucuğuna 5000 hücre düşecek şekilde $200 \mu \mathrm{L}$ besiyeri içinde ekildi. Başlangıçtan 24 saat sonra; pleytler inkübatörden alındı, kuyucuklardaki besiyerleri otomatik pipet ile çekilerek uzaklaştırıldı ve her bir kuyucuğa 200'er $\mu \mathrm{L}$ taze besiyeri eklendi. Taze besiyerleri üzerine son konsantrasyonlar1 5-500 $\mu \mathrm{g} / \mathrm{mL}$ olacak şekilde ekstrakttan ve $1-10 \mu \mathrm{g} / \mathrm{mL}$ olacak şekilde cisplatin çözeltisinden uygun hacimlerde ilaveler yapılıp hücrelerin bu maddelerin farklı konsantrasyonları ile $37^{\circ} \mathrm{C}$ 'de 72 saat inkübasyonu sağlandı. Süre sonunda kuyucuklardaki besiyerleri otomatik pipet ile çekilerek uzaklaştırıldı ve bütün kuyucuklara 190'ar $\mu \mathrm{L}$ taze besiyeri eklendi. Her bir kuyucuğa son konsantrasyonu $0.25 \mathrm{mg} / \mathrm{mL}$ olacak şekilde MTT boyası eklendi ve pleytler 3 saat daha $37^{\circ} \mathrm{C}$ 'de inkübe edildi. İnkübasyon sonunda kuyucuklardaki besiyerleri otomatik pipet ile çekilerek uzaklaştırıldı. Her bir kuyucuğa 200'er $\mu \mathrm{L}$ DMSO eklendi ve pleytler 90 dakika çalkalayıcıda bekletildi. Her bir kuyucukta oluşan mor tonundaki rengin absorbansı mikropleyt okuyucuda $570 \mathrm{~nm}$ dalga boyunda okundu. Her örneğin her bir konsantrasyonu için elde edilen absorbans değerinin, herhangi bir muamele görmeyen kontrol absorbans değerine oranı 100 ile çarpılarak her bir maddenin her bir konsantrasyonu için \% hücre canlılığ 1 hesapland. Elde edilen \% hücre canlılı̆̆ değerlerinin logaritmik konsantrasyona karşı grafiğe geçirilmesi ile elde edilen grafikten her bir hücre serisinde ekstrakt ve cisplatin için $\mathrm{IC}_{50}$ (yarı maksimum inhibitör konsantrasyonu) değerleri hesapland1.

\section{Istatistiksel Analiz}

Sonuçlar üç bağımsız deneyin ortalaması ve standart sapma (mean \pm SD) alınarak hesaplandı. Deney sonuçları, SPSS (Statistics Program for Social and Science) 13.0.1 istatistik programına yüklenerek normal dağılıma uygunlukları Kolmogorov-Smirnov testi ile kontrol edildi. Normal dağılıma uygun oldukları görüldükten sonra ANOVA testi, gruplar arasındaki ilişkinin ortaya konabilmesi için ise post-hoc Tukey analizleri kullanıldı. $\mathrm{p}<0.05$; istatistiksel olarak anlamlı kabul edildi.

\section{BULGULAR ve TARTISMA}

Oksidatif stres oksidan-antioksidan dengenin bozulması sonucu ortaya çıkan patolojik bir durum olup, kanser, kardiyovasküler ve otoimmün bozukluklar gibi pek çok hastalıkla ilişkilendirilmektedir (Aliyazicioglu ve ark. 2011). Antioksidan aktivite bu nedenle insan sağlığı için önem arz etmektedir ve özellikle son yıllarda pek çok biyolojik aktivitenin de antioksidan etkiden kaynaklandığı ileri sürülmeye başlanmıştır. Özellikle son yıllarda doğal ürünlerde bulunan fitokimyasalların oksidatif stres ile ilişkili hastalıklardan korunmak için önemli roller üstlenebilecekleri ortaya konmuştur. $\mathrm{Bu}$ fitokimyasalların antioksidan karakterleri ile serbest radikallerin hücre için zararlı etkilerini bertaraf ettiklerine inanılmaktadır. Test edilen doğal bir ürünün antioksidan aktivitesinin belirlenmesi, bu nedenle daha geniş kapsamlı çalışmalar için bir başlangıç noktası olarak kabul edilmektedir (Kaur ve Kapoor, 2001). Bitkisel kaynaklı ekstraktların antioksidan etkinliklerini belirlemek için birçok yöntem tanımlanmıştır. Toplam fenolik madde içeriği, toplam flavonoid madde içeriği ve indirgeyici güç analizleri elektron transferine dayalı antioksidan aktivite belirleme yöntemleridirler. $\mathrm{Bu}$ yöntemler antioksidan bir maddenin ortama konulan oksidan karakterdeki bir bileșiği indirgeyebilme kabiliyetini renk değişimi üzerinden belirlemeye olanak sağlamaktadırlar. Renkteki koyulaşma, dolayısıyla büyük absorbans değerleri maddenin antioksidan gücü ile orantılıdır (Dai ve Mumper, 2010). Hızlı, güvenilir ve maliyetlerinin düşük olmaları sebebiyle de doğal ürünlerin antioksidan karakterlerinin belirlendiği çalışmalarda sıklıkla kullanılmaktadırlar (Kaur ve Kapoor, 2001). Bu nedenlerden dolayı çalışmada $P$. vulgaris yapraklarından hazırlanan DMSO'lu ekstraktın antioksidan özellikleri, toplam fenolik madde tayini, toplam flavonoid madde tayini ve indirgeyici güç analizi metodları kullanılarak belirlendi ve sonuçlar Çizelge 1 'de gösterildi.

Orhan ve ark. (2012) P. vulgaris yapraklarının sulu ekstraktının toplam fenolik madde içeriğini $755 \mathrm{mg}$ gallik asit eşdeğeri/100 g örnek olarak bildirmişlerdir. Demir ve ark. (2014) ise etanollü $P$. vulgaris ekstraktının toplam fenolik madde içeriğini $12280 \mathrm{mg}$ gallik asit eşdeğeri/100 g örnek olarak bulurlarken, $45 \mu \mathrm{g} / \mathrm{mL}$ konsantrasyondaki ekstraktın indirgeyici gücünü \% 39.4 olarak hesaplamışlardır. Diğer Primula türleri üzerinde 
yapılan çalışmalarda ise Jaberian ve ark. (2013) Primula auriculata yapraklarının metanollü ekstraktının toplam fenolik ve flavonoid madde miktarlarını sırasıyla $836 \mathrm{mg}$ gallik asit eşdeğeri/100 g örnek ve $116 \mathrm{mg}$ kuersetin eşdeğeri/100 g örnek olarak bildirirlerken, Aslam ve ark. (2015) ise Primula denticulata yapraklarının etanollü ekstraktının toplam fenolik ve flavonoid madde miktarlarını sırasıyla $1593 \mathrm{mg}$ gallik asit eşdeğeri/100 g örnek ve 778 mg kateşin eşdeğeri/100 g örnek olarak rapor etmişlerdir. Çalışmada elde edilen antioksidan aktivite değerlerinin literatür verileriyle uyumlu olduğu görülmektedir. Aradaki farklılıkların kullanılan bitki türünden, bitkinin toplandığı bölgenin iklimsel, bitkisel özelliklerinden, çözücü türünden veya ekstraksiyon metodundan kaynaklanmış olabileceği düşünülmektedir.

Çizelge 1. Primula vulgaris yaprak ekstraktının antioksidan özellikleri ( $\mathrm{n}=3)$

\begin{tabular}{cc}
\hline Antioksidan Aktivite Tayin Yöntemi & \\
Toplam fenolik madde miktarl & \\
Toplam flavonoid madde miktarl & $* *$ \\
Demir indirgeyici güç*** & $4890.1 \pm 11.2$ \\
\hline
\end{tabular}

${ }^{*}$ Toplam fenolik madde miktarı mg gallik aside eşdeğer/100 g örnek olarak verildi

**Toplam flavonoid madde miktarı mg kuersetine eşdeğer/100 g örnek olarak verildi

${ }_{* * * *}$ Demir indirgeyici güç mg troloksa eşdeğer/100 g örnek olarak verildi

Kanser dünyadaki hastalık kaynaklı ölüm nedenlerinin en önemlilerinden birisidir. Dünya Sağlık Örgütü 2005-2015 yılları arasında yaklaşık 84 milyon insanın kanser nedeniyle hayatını kaybettiğini bildirmektedir (Behzad ve ark. 2014). Kanser tedavisinde sıklıkla kemoterapiye başvurulmakla birlikte zamanla ortaya çıkan toksik etkiler bu ilaçların kullanımını kısıtlamaktadır. Hem kanser vakalarının yüksek mortalite oran1, hem de kemoterapi ve radyoterapinin ciddi yan etkilerinin ortaya çıkması kanser hastalarını alternatif ve/veya tamamlayıc1 tedavilere yönlerdirmektedir (Unnati ve ark. 2013). İşte bu noktada doğal ürünlere yeni ilaç keşifleri için potansiyel hammadde gözüyle bakılmakta ve doğal ürünlerde bulunan fenolik bileşikler yapıları ve aktiviteleri ile ön plana çıkmaktadırlar. Bu nedenle doğal ürünlerin gerek bütün haldeki ekstraktlarının, gerekse de doğal ürünlerden izole edilen bileşiklerin antikanser etkilerinin araştırılması oldukça popüler çalışma alanlarından birisi haline gelmiştir. Doğal ürünlerin insanlar için kullanılabilirliğini belirlemede yapılacak ön çalışmalarda öncelikle in vitro metodların kullanılması önerilmektedir. Klinik denemeler ancak in vitro ve in vivo çalışmalardan pozitif sonuçların alınması durumunda tavsiye edilmektedir (Demir ve ark. 2016a; 2016b). Bir doğal bileşiğin kemopreventif ya da kemoterapötik açıdan etkili ve kabul edilebilir olduğunu gösteren bazı kriterler belirlenmiş olup, bu kriterlerin en önemlileri kullanılan doğal ürünün kanserli hücrelerde gösterdiği sitotoksik etkiyi normal hücrelerde sergilememesi ve birden fazla kanser hücre serisinde etki göstermesidir (Demir ve ark. 2016b). Bu nedenle $P$. vulgaris'in sitotoksik etkinliğinin de incelendiği bu çalışma 5 farklı kanser hücre serisi ve bir normal hücre serisi üzerinde in vitro koşullarda gerçekleştirildi. Günümüzde hücre canlılığının, proliferasyon hızının ve sitotoksisitenin belirlenmesi için sıklıkla tripan blue, MTT, nötral red ve laktat dehidrogenaz (LDH) gibi yöntemler kullanılmaktadır (Weyermann ve ark. 2005). Çalışmada ekstraktın sitotoksik etkinliğini belirlemek için hassas, kantitatif, güvenilir bir kolorimetrik metot olan ve benzer çalışmalarda da kullanılan (Demir ve ark. 2016a; 2016b) MTT yöntemi tercih edildi ve artan ekstrakt konsantrasyonuna karşı \% hücre canlılık değerlerinin değişimleri Şekil 1'de gösterildi. (Negatif kontrol grubuna göre hücre canlılığını istatistiksel olarak anlamlı şekilde $(\mathrm{p}<0.05)$ azaltan konsantrasyonlar * ile gösterildi).

Literatürde yayınlar arası bütünlüğün sağlanması için doğal ürün ekstraktı ya da herhangi bir kimyasal maddenin sitotoksik etkinliği $\mathrm{IC}_{50}$ değerleri cinsinden ifade edilmektedir. $\mathrm{IC}_{50}$; Amerikan Gıda ve İlaç Dairesi (FDA) tarafindan negatif kontrol grubuyla kıyaslandığında \% 50 absorbans azalması oluşturan ilaç ya da kimyasal konsantrasyonu olarak tarif edilmektedir (Demir ve ark. 2016a). Ekstraktın her bir hücre serisi üzerindeki sitotoksik etkisi hücre büyüme eğrilerinden yola çıkılarak $\mathrm{IC}_{50}$ cinsinden hesapland1 ve sonuçlar Çizelge 2'de sunuldu.

Sonuçlar incelendiğinde ekstraktın çalışılan 5 kanser hücre serisindeki $\mathrm{IC}_{50}$ değerlerinin 133.3-253.8 $\mu \mathrm{g} / \mathrm{mL}$ konsantrasyon aralığında değiştiği görülmektedir. Kanser hücre serilerinde elde edilen değerler normal fibroblast hücrelerinde elde edilen değerle kıyaslandığında, ekstraktın sitotoksik etkisinin seçici olduğu anlaşılmakta ve en seçici sitotoksik etkinin MCF7 hücre serisinde elde edildiği görülmektedir. Literatürdeki Primula türlerinin sitotoksik etkinliğini konu alan diğer çalışmalarda ise; Primula macrophylla'nın etanollü ekstraktı ile etil asetat, kloroform ve benzen fraksiyonlarının sitoksik etkisi brine shrimp (Artemia salina) yöntemi ile incelenmiş ve en etkili aktivitenin etanollü ham ekstraktta gözlendiği bildirilmiştir (Najmus-Saqib ve ark. 2009). Behzad ve ark. (2014) Primula auriculata'nın metanollü ekstraktının MCF-7, HepG2 ve HT-29 hücre serilerinde normal bovin böbrek hücrelerine göre seçici bir sitotoksik etki gösterdiğini bildirmişlerdir. Aynı çalışmada ekstraktın $100 \mu \mathrm{g} / \mathrm{mL}$ konsantrasyona kadar A549 hücre serisinde herhangi bir sitotoksik etkisi görülmemiştir.

Literatürde Primula cinsi bitkilerin sitotoksik etkinliğini inceleyen az sayıda çalışma bulunmaktadır. Bununla birlikte Primulaceae ailesinin üyelerinden Dionysia termeana'nın metanollü ekstraktının insan miyelojenik lösemi (K562), T-lenfositik lösemi (Jurkat), mesane (Fen) ve akciğer kanseri (A549) hücre serilerinde konsantrasyona bağlı sitotoksik etki gösterdiği bildirilmiştir. Yine aynı çalışmada ekstraktın kan kökenli hücre serilerindeki (K562 ve Jurkat) sitotoksik etkisinin apoptozu arttırmasından kaynaklandığı da belirlenmiştir (Amirghofran ve ark. 2007). 

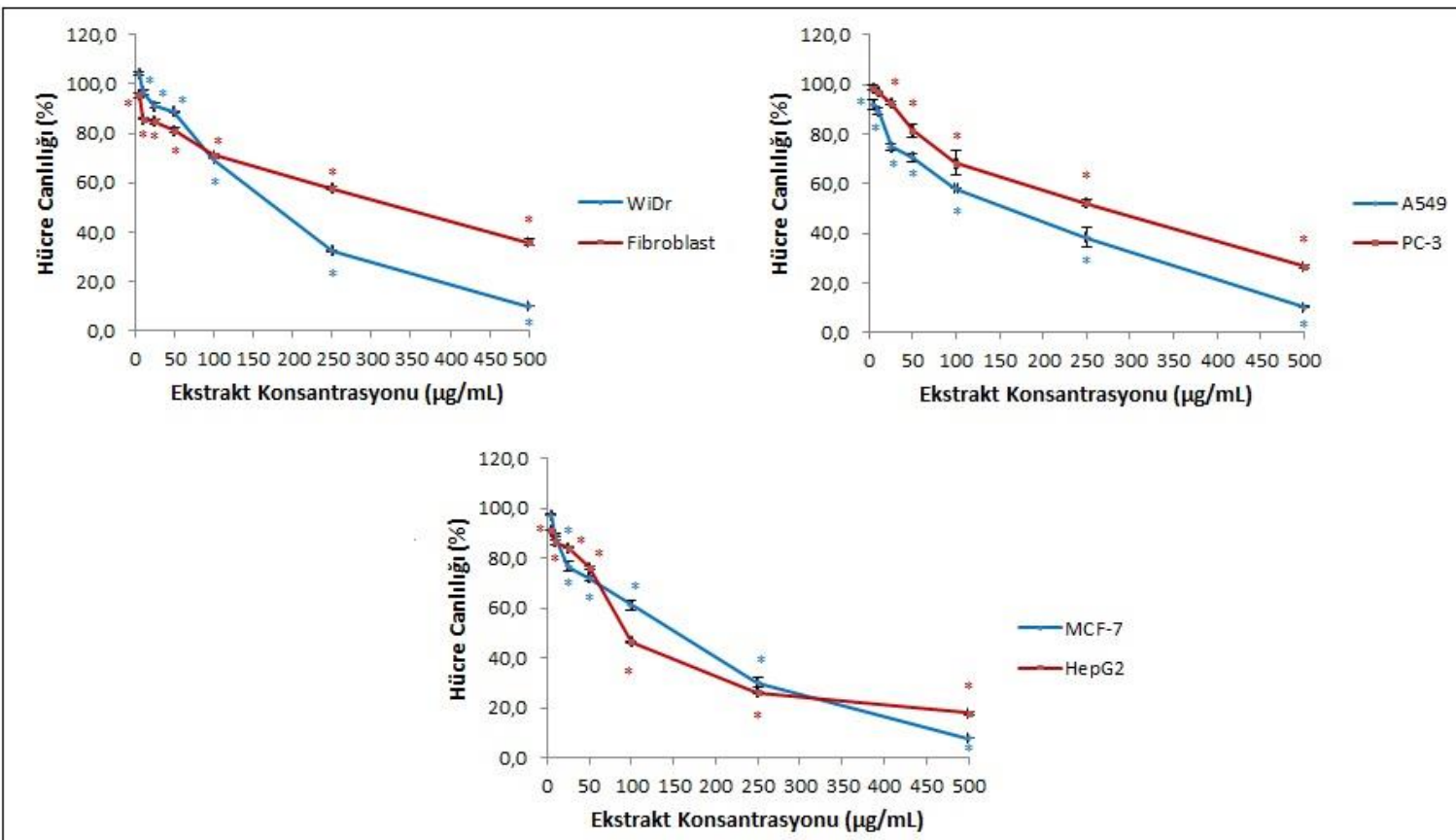

Şekil 1. Primula vulgaris yaprak ekstraktının farklı konsantrasyonlarının 72 saatlik inkübasyon süresinde hücrelerin canlılı̆̆ üzerine etkisi ( $\mathrm{n}=3)$

Çizelge 2. Primula vulgaris yaprak ekstraktının ve cisplatinin sitotoksik etkisi $\left(\mathrm{IC}_{50}, \mu \mathrm{g} / \mathrm{mL}\right)(\mathrm{n}=3)$

\begin{tabular}{lcccccc}
\hline & A549 & HepG2 & MCF-7 & PC-3 & WiDr & Fibroblast \\
\cline { 2 - 7 } Ekstrakt & $144.3 \pm 6.4$ & $148.3 \pm 3.2$ & $133.3 \pm 4.5$ & $253.8 \pm 10.9$ & $160.8 \pm 2.5$ & $316.9 \pm 10.8$ \\
Cisplatin & $0.69 \pm 0.03$ & $2.54 \pm 0.02$ & $0.52 \pm 0.03$ & $0.75 \pm 0.01$ & $1.29 \pm 0.01$ & $4.96 \pm 0.1$ \\
\hline
\end{tabular}

Yapılan bir başka çalışmada ise yine Primulaceae ailesinin üyelerinden Lysimachia vulgaris'in sulu ekstraktı ile hekzan, diklormetan ve metanol fraksiyonlarının insan meme (MCF-7) ve karaciğer (HepG2/C3A) hücre serilerinde $200 \mu \mathrm{g} / \mathrm{mL}$ konsantrasyona kadar bir sitotoksik etkisi olmadığ gösterilmiştir (Pehlivan Karakas ve ark. 2015). Sadece ekstrakt halinde değil çeşitli Primula türlerinden izole edilen bileşiklerin de sitotoksik etkinliklerinin incelendiği çalışmalar mevcuttur. Tokalov ve ark. (2004) Primula denticulata'dan izole edilen 5-hidroksiflavon, 2'-hidroksiflavon, 5,2'-dihidroksiflavon ve 5,8dihidroksiflavon bileşiklerinin insan akut miyeloid lösemi (HL-60) hücre serisinde hücre döngüsünü durdurarak ve apoptozu arttırarak antiproliferatif etki gösterdiklerini bildirmişlerdir.

Polifenoller sekonder bitkisel metabolitlerin önemli bir sınıfi olup kuvvetli antioksidan özellik sergileyebildikleri bildirilmektedir. Polifenolik bileşiklerin antioksidan özellikleri; reaktif oksijen türlerine elektron verebilmeleri, radikal oluşumunu hızlandıran ağır metal iyonlarını şelatlayabilmeleri ve antioksidan/detoksifikasyon enzimlerini uyarabilmeleri mekanizmaları ile açıklanmaktadır (Surh, 2003; Turan ve ark. 2015). Özellikle son y1llarda polifenollerin kanser hücrelerinin çoğalmasını engelleyebildiğine ve bu hücrelerde kontrollü hücre ölümü olan apoptozu arttırabildiğine dair çalışmalar hız kazanmıştır. Fenolik bileşiklerin antikanser etkinliklerinin ise; hücre sinyalizasyonunu ve antioksidan enzimleri modüle edebilmeleri, hücre döngüsünü durdurabilmeleri ve apoptozu indükleyebilmeleri özelliklerinden kaynaklandığı ileri sürülmektedir $(\mathrm{Hu}, 2011) . \mathrm{Bu}$ bileşiklerin özellikle DNA sentezini inhibe edebilme özellikleri ile mitozu durdurabilmeleri sonucunda antiproliferatif etki gösterdikleri de bildirilmektedir (Tokalov ve ark. 2004). Primula türlerinin kaempferol, kuersetin, 5-hidroksi pirogallol, apigenin, kateşin türevleri, gallik asit, rosmarinik asit, $p$-kumarik asit, ferulik asit ve ellagik asit gibi fenolik bileşikler yönünden zengin oldukları yapılan çalışmalarla gösterilmiş olup (Mostafa ve ark. 2014, Shostak ve ark. 2016) bu bileşiklerin çeşitli kanser türleri üzerine antikanser özelliklerine dair literatürler de mevcuttur (Ravishankar ve ark. 2013). Çeşitli doğal ürünlerden hazırlanan ekstraktların sitotoksik özelliklerinin incelendiği çalışmalarda, öncelikle ekstraktın bütün haldeki etkisinin incelendiği ve sonuçların sinerjik etkiye atfedildiğ görülmektedir. İlerleyen çalışmalarda ise etkinin görüldüğü fraksiyondan çeşitli izolasyonlar yapılarak içerikteki bileşenlerin bireysel etkileri değerlendirilmektedir (Bufalo ve ark. 2009). Buradan hareketle $P$. vulgaris yaprak ekstratının sitotoksik etkinliğine içerdiği bütün bu fenolik bileşiklerin katk1 verdiği düşünülmektedir. 


\section{SONUC}

$\mathrm{Bu}$ çalışma Primula vulgaris yaprak ekstraktının antioksidan özelliklerinin ve in vitro sitotoksik etkisinin kapsamlı olarak incelendiği ilk çalışmadır. Ekstraktın sitotoksik etkisinin hangi mekanizmalar üzerinden gerçekleştiğinin belirlenebilmesi için daha kapsamlı çalışmalar gerekmektedir. Kullanılan numunelerin içeriğinin aydınlatılıp, çalışmaların farklı kanser hücre serilerinde ve deneysel yaklaşımlarla devam ettirilmesinin, klinik çalışmaların önünü açabileceği düşünülmektedir.

\section{TEŞEKKÜR}

Bitki kimliklendirilmesi konusundaki yardımlarından dolayı Karadeniz Teknik Üniversitesi Eczacılık Fakültesi öğretim üyesi Prof. Dr. Ufuk Özgen’e teşekkür ederiz.

\section{KAYNAKLAR}

Aliyazicioglu Y, Demir S, Turan I, Cakiroglu TN, Akalin I, Deger O, Bedir A 2011. Preventive and protective effects of Turkish propolis on $\mathrm{H}_{2} \mathrm{O}_{2}$ induced DNA damage in foreskin fibroblast cell lines. Acta Biologica Hungarica, 62(4): 388-396.

Amirghofran Z, Bahmani M, Azadmehr A, Ashouri E, Javidnia K 2007. Antitumor activity and apoptosis induction in human cancer cell lines by Dionysia termeana. Cancer Investigation, 25: 550-554.

Aslam K, Nawchoo IA, Bhat MA, Ganie AH, Aslam N 2014. Ethno-pharmacological review of genus Primula. International Journal of Advanced Research, 2(4): 29-34.

Aslam K, Nawchoo IA, Ganai BA 2015. In vitro antioxidant, antibacterial activity and phytochemical studies of Primula Denticulata-an important medicinal pant of Kashmir Himalaya. International Journal of Pharmacological Research, 5(3): 49-56.

Behzad S, Pirani A, Mosaddegh M 2014. Cytotoxic activity of some medicinal plants from Hamedan district of Iran. Iranian Journal of Pharmaceutical Research, 13: 199-205.

Behzad S, Ebrahim K, Mosaddegh M, Haerid A 2016. Primula auriculata extracts exert cytotoxic and apoptotic effects against HT-29 human colon adenocarcinoma cells. Iranian Journal of Pharmaceutical Research, 15(1): 311-322.

Bufalo MC, Candeias JM, Sforcin JM 2009. In vitro cytotoxic effect of Brazilian green propolis on human laryngeal epidermoid carcinoma (HEp-2) cells. Evidence-Based Complementary and Alternative Medicine, 6(4): 483-487.

Dai J, Mumper RJ 2010. Plant phenolics: Extraction, analysis and their antioxidant and anticancer properties. Molecules, 15: 7313-7352.

Demir N, Alayli Gungor A, Nadaroglu H, Demir Y 2014. The antioxidant and radical scavenging activities of Primrose (Primula vulgaris). European Journal of Experimental Biology, 4(2): 395-401.

Demir S, Aliyazicioglu Y, Turan I, Misir S, Mentese A, Ozer Yaman S, Akbulut K, Kilinc K, Deger O 2016a. Antiproliferative and proapoptotic activity of Turkish propolis on human lung cancer cell line. Nutrition and Cancer, 68(1): 165-172.

Demir S, Turan I, Aliyazicioglu Y 2016b. Selective cytotoxic effect of Rhododendron luteum extract on human colon and liver cancer cells. Journal of Balkan Union of Oncology, 21(4): 883-888.

$\mathrm{Hu}$ ML 2011. Dietary polyphenols as antioxidants and anticancer agents: more questions than answers. Chang Gung Medical Journal, 34(5): 449-460.

Hussain SA, Sulaiman AA, Balch C, Chauhan H, Alhadidi QM, Tiwari AK 2016. Natural polyphenols in cancer chemoresistance. Nutrition and Cancer, 68(6): 879-891.

Jaberian H, Piri K, Nazari J 2013. Phytochemical composition and in vitro antimicrobial and antioxidant activities of some medicinal plants. Food Chemistry, 136: 237-244.

Kaur C, Kapoor HC 2001. Antioxidants in fruits and vegetables-the millennium's health. International Journal of Food Science and Technology, 36: 703725.

Moreno MI, Isla MI, Sampietro AR, Vattuone MA 2000. Comparison of the free radical-scavenging activity of propolis from several regions of Argentina. Journal of Ethnopharmacology, 71(1-2): 109-114.

Mosmann T 1983. Rapid colorimetric assay for cellular growth and survival: application to proliferation and cytotoxicity assays. Journal of Immunological Methods, 65: 55-63.

Mostafa FA, Gamal MA, Sabrin IRM, Ehab, ES 2014. Antioxidant and anti-inflamatory activities of phenolic constituents from Primula elatior L. aerial part. International Journal of Pharmacognosy and Phytochemical Research, 6(1): 74-78.

Najmus-Saqib Q, Alam F, Ahmad M 2009. Antimicrobial and cytotoxicity activities of the medicinal plant Primula macrophylla. Journal of Enzyme Inhibition and Medicinal Chemistry, 24(3): 697-701.

Orhan DD, Ozcelik B, Hosbas S, Vural M 2012. Assessment of antioxidant, antibacterial, antimycobacterial, and antifungal activities of some plants used as folk remedies in Turkey against dermatophytes and yeast-like fungi. Turkish Journal of Biology, 36: 672-686.

Oyaizu M 1986. Studies on product of browning reaction prepared from glucose amine. Japanese Journal of Nutrition, 44: 307-315.

Pehlivan Karakas F, Birinci Yildirim A, Bayram R, Yavuz MZ, Gepdiremen A, Ucar Turker A 2015. Antiproliferative activity of some medicinal plants on human breast and hepatocellular carcinoma cell lines and their phenolic contents. Tropical Journal of Pharmaceutical Research, 14(10): 1787-1795.

Ravishankar D, Rajora AK, Greco F, Osborn HM 2013. Flavonoids as prospective compounds for anti-cancer therapy. International Journal of Biochemistry \& Cell Biology, 45(12): 2821-2831.

Shostak LG, Marchyshyn SM, Kozachok SS, Karbovska RV 2016. Investigation of phenolic compounds of 
Primula veris L. Journal of Education, Health and Sport, 6(5): 424-432.

Singh S, Ali S, Singh M 2014. Biological screening of plants extract showing hypoglycaemic and wound healing properties: Capparis zeylanica and Primula denticulata. American Journal of Phytomedicine and Clinical Therapeutics, 2(12): 1338-1345.

Slinkard K, Singleton VL 1977. Total phenol analysis: automation and comparison with manual methods. American Journal of Enology and Viticulture, 28: 49. 55.

Surh YJ 2003. Cancer chemoprevention with dietary phytochemicals. Nature Reviews Cancer, 3(10): 768780.

Tokalov SV, Kind B, Wollenweber E, Gutzeit HO 2004. Biological effects of epicuticular flavonoids from Primula denticulata on human leukemia cells.
Journal of Agricultural and Food Chemistry, 52(2): 239-245.

Turan I, Deger O, Aliyazicioglu Y, Demir S, Kilinc K, Sumer A 2015. Effects of Turkish propolis on expression of hOGG-1 and NEIL-1. Turkish Journal of Medical Sciences, 45: 804-811.

Turker AU, Usta C 2008. Biological screening of some Turkish medicinal plant extracts for antimicrobial and toxicity activities. Natural Product Research, 22(2): 136-146.

Unnati S, Ripal S, Sanjeev A, Niyati A 2013. Novel anticancer agents from plant sources. Chinese Journal of Natural Medicines, 11(1): 16-23.

Weyermann J, Lochmann D, Zimmer A 2005. A practical note on the use of cytotoxicity assays. International Journal of Pharmaceutics, 288: 369-376. 